\title{
SPEED OF ADJUSTMENT TOWARDS TARGET LEVERAGE IN THE ASEAN COUNTRIES
}

\author{
Meishan Chua* \\ Universiti Teknologi Mara, Universiti Putra Malaysia \\ Nazrul Hisyam Ab Razak \\ Universiti Putra Malaysia \\ Annuar Md Nassir \\ Xiamen University Malaysia \\ Mohamed Hisham Yahya \\ Universiti Putra Malaysia
}

\begin{abstract}
This study aims to investigate the speed of adjustment towards target total debt, long-term debt and shortterm debt of the Association of South East Asian Nations (ASEAN) namely Malaysia, Singapore, Indonesia and Thailand. The sample of this study included 400 publicly listed firms from 2007 to 2017 . Analyses were done with two-step System Generalised Method of Moments (SYS-GMM). Using large sample, the results showed that ASEAN firms are under-adjusted and adjusting with the speed of $30.95 \%, 37.49 \%$ and $40.11 \%$ toward total debt, long-term debt and short-term debt, accordingly. To close half of the leverage gap, ASEAN firms need 1.87, 1.62 and 1.35 years for total debt, long-term debt and short-term debt, respectively. The results based on individual country indicated that each country has its own adjustment speed to achieve the target leverage. This study suggests that ASEAN firms are attempting to alter the leverage to its optimum.
\end{abstract}

Keywords: Speed of adjustment, System Generalised Method of Moments (SYS-GMM), book value total debt, book value long-term debt, book value short-term debt, ASEAN.

Received: 18 March 2019

Accepted: 30 December 2020

https://doi.org/10.33736/ijbs.3177.2021

\section{INTRODUCTION}

Optimum capital structure is one of the methods used to maximise shareholders' wealth. According to Dynamic Capital Structure Theory (DCS), firms are unlikely to have a static optimal capital structure as they are facing with the transaction costs when restructuring debt and equity ratio. Even a small change in debt decisions leads to a larger deviation to adjust towards the target debt (Fischer, Heinkel \& Zechner, 1989). In DCS, adjustment cost is a critical factor that influences firms' target leverage; the higher the adjustment cost, the slower is the speed of adjustment (SOA)

\footnotetext{
- Corresponding author: Universiti Teknologi Mara, Puncak Alam \& Universiti Putra Malaysia, Serdang, Malaysia; Tel:60129599133; Email: meishan5388@gmail.com
} 
towards target leverage, which consequently generates a loss in firm value. Another significant reason to study DCS is that the static capital structure model fails to capture the long-run determinant of capital structure.

Getzmann, Lang and Spremann (2015) proved highest adjustment cost (slowest SOA) for Asian countries as a comparison to European countries and the USA (SOA: $55 \%$ to $77 \%$, 40\% to $61 \%$ and $35 \%$ to $59 \%$, respectively). Despite the interesting findings from Getzmann et al., (2015), the empirical evidence are surprisingly lacking from ASEAN context, especially the individual countries in ASEAN. Thus, a study from ASEAN context is necessary as it has different stage of financial market development prone to be an important indicator to determine the availability of funds that directly influences the mixture between debt and equity decision (Ahmad \& EtudaiyeMuhtar, 2017; Oztekin \& Flannery, 2012; Lööf, 2004). What is more, ASEAN has different business environments compared to the developed countries where the large shareholders often have the ultimate control over the management. In the circumstance, the capital structure decision might be the combination between large shareholders and top management as ASEAN are practicing the collectivist norm in managing firms (Antonczyk \& Salzmann, 2014). Another reason to study ASEAN is because of the weak external corporate governance (such as legal system in protecting minority interest and market for corporate control) in ASEAN firms. This indicates the importance to study debt in ASEAN as it has the controlling effect to discipline the management (Berglöf, 1990). Because of these distinct business environments, the empirical evidence from the past that are not based on ASEAN may have little support to portray the DCS of ASEAN. Thus, this present study investigated DSC (mainly the speed of adjustment) for ASEAN firms (including Malaysia, Singapore, Indonesia and Thailand) in total and separated the sample into individual country to capture the differences of institutional setting.

This study provides several contributions to the DCS studies. First, by applying the two-step system generalised method of moments (GMM), it was found that a large sample of ASEAN firms are adjusting toward target with the speed of $30.95 \%, 37.49 \%$ and $40.11 \%$ for book value total leverage, long-term leverage and short-term leverage, accordingly. With these speeds, ASEAN countries require $1.87,1.62$ and 1.35 years to close half of the leverage gap. The reported result of SOA towards target total debt in this study were different compared to those from Getzmann et al., (2015) study, but the SOA were within the range of SOA as per industry in Asia as reported in their results. When separated to individual countries, it was found that each country has its own SOA. The range varied from $29.11 \%$ to $41.21 \%$ with Malaysia being the slowest and Singapore being the quickest. These findings show a separation of ASEAN countries from Asia region, which is indeed an issue that academicians should concern since using the findings from previous studies to predict the SOA might cause a misleading SOA of ASEAN countries. These findings stressed out the important dynamic nature of capital structure. Conversely, the first contribution of this study is that it specifically shows the SOA of ASEAN and each of the four individual countries, which has significantly fill the research gap of the ASEAN study.

This study provides several contributions to the DCS studies. First, by applying the two-step system generalised method of moments (GMM), it was found that a large sample of ASEAN firms are adjusting toward target with the speed of $30.95 \%, 37.49 \%$ and $40.11 \%$ for book value total leverage, long-term leverage and short-term leverage, accordingly. With these speeds, ASEAN countries require $1.87,1.62$ and 1.35 years to close half of the leverage gap. The reported result of SOA towards target total debt in this study were different compared to those from Getzmann et al., 
(2015) study, but the SOA were within the range of SOA as per industry in Asia as reported in their results. When separated to individual countries, it was found that each country has its own SOA. The range varied from $29.11 \%$ to $41.21 \%$ with Malaysia being the slowest and Singapore being the quickest. These findings show a separation of ASEAN countries from Asia region, which is indeed an issue that academicians should concern since using the findings from previous studies to predict the SOA might cause a misleading SOA of ASEAN countries. These findings stressed out the important dynamic nature of capital structure. Conversely, the first contribution of this study is that it specifically shows the SOA of ASEAN and each of the four individual countries, which has significantly fill the research gap of the ASEAN study.

Second, despite a strict notion of leverage that only refers to long-term debt, this study showed that the ASEAN firms also adjusted towards the target short-term debt with a quicker speed compared to long-term debt. The present findings exhibited the importance to include the short-term debt as a variable in countries with significant portion of short-term debt usage like ASEAN ${ }^{1}$. The individual countries also exhibited similar trend. Thus, this study suggested that DCS studies shall not overlook on the speed of adjustment towards short-term debt since short-term debt has more controlling effect to discipline the managers. Firms would be benefited from short-term debt as it has a short maturity commitment that motivates the managers to choose positive NPV projects (Jensen, 1986; Myers, 1977; Zhu, 2014), lower interest rate (Fosberg, 2012) and lower credit risk of default (Myers \& Majluf, 1984). Therefore, the second contribution of this study is that it included short-debt as the main variable to study the SOA, which typically has been unnoticed from the dynamic capital structure

Third, this study has produced more consistent and efficient estimator with the application of more advanced method in a case of dynamic panel data. Until now, there are researchers who are interested in studying the dynamic capital structure for ASEAN; however, majority of these studies' estimators may not be as efficient as that in this study with a use of SYS-GMM. For example, Haron, Ibrahim, Nor \& Ibrahim (2013a) [Thailand], Haron, Ibrahim, Nor \& Ibrahim (2013b) [Malaysia], Nor, Haron, Ibrahim, Ibrahim \& Alias (2011)[Malaysia, Thailand and Singapore], Haron (2014) [Malaysia] and Haron (2016) [Indonesia] used the Diff-GMM for the estimation. This method has been proven unable to control the influence of high persistent variables, more biases in small sample and less efficient compared to SYS-GMM. In the meantime, the empirical evidence provided by Soekarno, Kitri \& Utomo, (2016), Soekarno, Kitri, \& Utomo (2015) [Indonesia] and M'ng, Rahman and Sannacy (2017) [Malaysia, Singapore and Thailand] may suffer from downward bias on lagged dependent variables as a result from Fixed Effect model. What is more, part of the estimation model used in Nor et al., (2011), Haron et al., (2013a) and Haron et al., (2013b) studies did not pass the validity instrument test with the absence of second order serial correlation test to achieve consistent and efficient estimators. To correct the inefficiency of variables, the command "xtdpd" in Stata was used in this study instead of "xtdpdsys" as it provides the flexibility to use deeper lags to find valid instruments for the proposed specification model. Consequently, the third contribution of this study is that it produces more efficient coefficient of lagged dependent variables, which translated to less bias of SOA towards target leverage. In this regard, this study confidently concluded the existence of adjustment cost in achieving firms' target leverage for ASEAN that is consistent to the DCS theory. Apart to academic

\footnotetext{
${ }^{1}$ short-term debt represents a part of ASEAN firm capital structure, which is $18 \%$ of the total debt (source: author's own calculation).
} 
contribution, this study also provides the evidence on how quickly the firms are trying to achieve the optimal leverage as a means to maximise the shareholders' wealth, which are useful to the policy makers for investment purpose.

\section{LITERATURE REVIEW \& HYPOTHESES DEVELOPMENT}

\subsection{Dynamic Capital Structure Theory}

DCS theory is introduced by Kane, Marcus and McDonald (1984) who argued firm bankruptcy costs alone could not explain the observed debt ratios, but other factors such as moral hazards could be the factors that influence firm leverage. Their model demonstrated that firms are unable to adjust the leverage before the outstanding leverage becomes due. Built upon their model, Fischer et al., (1989) incorporated transaction costs due to recapitalisation into the static trade-off model expressively as a readjustment of the debt ratio depending benefit of readjustment that exceeded the associated costs (Schröder \& Sosman, 2016). Instead of just one specific point of target leverage, firms would only adjust toward the target leverage within specific ranges. These ranges are depending on the adjustment costs and costs of deviation from the target (Getzmann, Lang \& Spremann, 2014). Most empirical evidence supported a dynamic nature of debt rather than static nature of debt (also known as static trade-off theory).

\subsection{Empirical Evidence from Western Countries}

The earlier work on dynamic capital structure can be traced back to Banerjee, Heshmati \& Wihlborg (1999) who studied the UK and US firms from 1989 to 1996. They recognised the importance of dynamic nature of debt and incorporated this factor to the dynamic adjustment model (also known as reduced-form model). They reported that the UK and the US firms partially adjusted towards the target leverage, which was more profound in bigger firms with a slow adjustment. This suggests for an error if the capital structure studies do not incorporate the dynamic nature of debt.

Lööf (2004) acknowledged the different for SOA for market (the US and UK) and bank-based system (Swedish) from year 1991 to 1998. The author documented an SOA of $8 \%$ to $14 \%$ for Swedish firms, $11 \%$ to $65 \%$ for UK firms and the actual leverage of the US firms that was close to the target leverage. Their findings advocated for a distinctive SOA for different country.

Still, from the USA firms but with different time-frame (1965 to 2001), Flannery and Rangan (2006) introduced the partial adjustment model to estimate the SOA in a single step. Using the Diff-GMM, they found that the SOA towards market debt of US firms was $34.4 \%$ with the adjustment cost of 0.656. Converted into years, it would take firms to complete more than half of their required leverage adjustment in less than two years.

Cook and Tang (2010) and Dang, Kim and Shin (2014) investigated the SOA by considering the macroeconomic conditions for US firms. Cook and Tang (2010) reported that adjustment speed ranging from $40 \%$ to $74.9 \%$ and $51.2 \%$ to $71.5 \%$ are in good macroeconomic condition, whereas that ranging from $35.9 \%$ to $72.9 \%$ and $34 \%$ to $72.7 \%$ are in bad macroeconomic conditions, respectively, to book leverage and market leverage. Their results covered from the year 1977 to 2006. Meanwhile, Dang et al., (2014) covered the period from 2002 to 2012 and the 
macroeconomic condition they examined was global financial crisis (2007 to 2009). They presented the SOA toward book leverage of US firms ranging from $38 \%$ and $24 \%$ for pre-crisis and crisis period, respectively. Both results deduced a quicker adjustment speed during good macroeconomic condition and slower adjustment speed during the bad macroeconomic condition. Other than that, Dang et al., (2014) also found more constrained firms (proxies by high growth, large investment, small size, high volatile earnings and higher Size-Age index) that adjusted more quickly than less constrained firms. Interestingly, during the crisis period, only firms with large deviation made more attempts to adjust toward target leverage with no attempt made by small deviation firms.

From another perspective, Faulkender, Flannery, Watson and Smith (2012) studied the impact of firms' financial health to the SOA from year 1965 to 2006 for US firms. Specifically, they found that firms adjusted with ranges from $23 \%$ to $26 \%$ for zero cash flow realisation firms. However, when the authors accounted the cash flow realisation in the estimation, the leverage deviation adjustment speed was in excess of 50\% with the number increased to greater than $70 \%$ for overlevered firms. Furthermore, they documented that financially constrained firms adjusted slower than unconstrained firms for under-levered firms, but more quickly for over-levered firms. Finally, the market timing variables were also seen to affect the adjustment speed from the results based on book value leverage. Their findings are consistent with the idea that firms with low adjustment cost are likely to adjust quicker (Fischer et al., 1989).

Similar to Lööf (2004), Drobetz, Schilling and Schroder (2015) analysed the SOA based on marketbased and bank-based system with greater sample. Using the G7 countries (US, Canada, UK, Germany, France, Italy and Japan), they found that the SOA towards book leverage was $25 \%$ per year on a large international sample from year 1992 to 2011. Also, the authors reached similar findings as Lööf (2004) where they discovered that market-based countries (Canada, the UK and the US - SOA: $35.4 \%, 32 \%$ and $26.1 \%$, respectively) adjusted quicker than bank-based countries (Japan and Italy - SOA: $19.5 \%$ and $22.6 \%$, respectively). Additionally, business cycle of a firm was reported as an important factor to influence the SOA.

From risk perspective, Rashid (2016) analysed the effects of the firm-specific and macroeconomic risks on costs and benefits of capital structure adjustments for large panel of the UK manufacturing firms. Without the risk factor, firms adjusted with a speed of $45.2 \%$ towards book leverage. However, with the inclusion of firm-specific and macroeconomic risks, the firms adjusted with a slower speed of $35.7 \%$. This indicates a slower adjustment when the firms are associated with higher risk. Other than that, the financial flexibility to issue debt and equity also significantly affected the firms' SOA. Covering the US firms from 1982 to 2011, Devos, Rahman and Tsang (2017) showed that debt covenant was negatively associated with firm leverage, implying that higher intensity in covenant protection lowers the speed of leverage adjustment. Specifically, the speed of adjustment towards book leverage was reduced by $40 \%$ and $45 \%$ for total debt and long term debt ratios, respectively. This reduction required 26 to 31 months longer to adjust towards target level when firms have covenant provisions.

\subsection{Empirical evidence from Asian countries}

Turning to empirical evidence in Asia, Getzmann et al., (2015) made a comparison of SOA for Asia, Europe and the US. Applying the SYS-GMM, they found that SOA per industry lies in 
between $25 \%$ to $45 \%$ for Asia, $41 \%$ to $65 \%$ for Europe and $39 \%$ to $60 \%$ for the US based on book leverage, whereas $12 \%$ to $47 \%$ for Asia, $36 \%$ to $66 \%$ for Europe and $41 \%$ to $91 \%$ for the US based on market leverage. The study indicated that the cost of adjustment of Asian countries was the highest compared to European firms and the US firms. In aggregation, the SOA toward book and market leverage were $33 \%$ and $34 \%, 54 \%$ and $56 \%$, and $47 \%$ and $63 \%$ for Asia, Europe and the US, respectively. The results conformed to the notion that different countries lead to different SOA as a result from a distinctive institutional setting.

In China, Yang, Albaity \& Hassan (2015) examined the SOA for Chinese A-share listed firms from the year 2008 to 2013. They found that Chinese firms adjusted at $36.7 \%$ per year and took 1.52 years to achieve the half-life of target book debt; this was quicker compared to other countries (such as US, G7 countries and Malaysia) as a result from active investment opportunities in China. In similar setting, Rehman, Wang and Yu (2016) analysed the impact of different life cycles on SOA for Chinese non-financial firms from 1996 to 2014. The author reported different ranges of SOA following growth, maturity and decline stage $(88 \%, 53 \%$ and $26 \%$, respectively, for total leverage ratio). What is more, they also exhibited interesting findings in regard to different dependent variables, specifically the SOA of 78\%-44\%-29\% when they used long-term debt, whereas SOA of $90 \%-75 \%-60 \%$ for short-term debt. Their findings show that SOA can vary when time-effect is taken into account.

Still in Asia, Buvanendra, Sridharan \& Thiyagarajan (2017) examined the SOA for South Asia Indian and Sri Lanka firms from year 2004 to 2013. Using the fixed effect model to estimate the determinant of target capital structure and System GMM to estimate the SOA, they found that Indian firms adjusted quicker at $26 \%$ per year compared to Sri Lanka firms that adjusted at $45.4 \%$ per year. Their study indicated different SOA even both countries were originated from similar region.

Moving to South East Asia region, Nor et al., (2011) studied the SOA for Malaysia, Singapore and Thailand from year 2000 to 2009. Applying the Diff-GMM estimation, the study discovered that the SOA toward book value and market value total debt were $57 \%$ and $53.88 \%, 65.46 \%$ and $49.48 \%$, and $28.04 \%$ and $64.1 \%$, respectively, to Malaysia, Singapore and Thailand. Apart from that, they examined the adjustment speed for long-term and short-term debts. The adjustment speed towards book value and market value long-term debt was $34.66 \%$ and $42.54 \%, 47.30 \%$ and $59.61 \%$ and $30.63 \%$ and $68.07 \%$, respectively, to Malaysia, Singapore and Thailand. Meanwhile, the adjustment speed towards book value and market values short-term debt was $51.61 \%$ and $97.34 \%$, $30.82 \%$ and $51.92 \%$ and $67.02 \%$ and $94.27 \%$, respectively, to Malaysia, Singapore and Thailand.

Looking only at the individual country, Ting (2016) studied the SOA for Malaysian firms from 2004 to 2013 with results showing that Malaysian firms adjusted approximately $21 \%$ to $26 \%$ per year for book value and market value total leverage, respectively. Also in Malaysian based study, Nejad and Wasiuzzaman (2015) found the adjustment speed towards market leverage of $40 \%$ for the period of 2005 to 2010 .

Other than Malaysia, Soekarno, Kitri and Utomo (2015) examined the impact of financial crisis on the SOA of Indonesian state owned enterprises (SOE). Dividing the period into 1996-2007 for precrisis and 2009-2014 for post-crisis, their study showed a lower cost of adjustment before crisis than after crisis. Specifically, the SOE have adjusted with $39.79 \%$ before crisis and $25.99 \%$ after 
crisis, which translated to 9.07 and 15.29 years to reach the capital structure, respectively. Like western countries' empirical studies, the study concluded that firms would take longer period to adjust towards target leverage during bad economics condition. In addition, Soekarno, Kitri and Utomo (2016) in a study on period ranging from 1995 to 2013 revealed that Indonesian SOEs were closed by two-third of the gap to target leverage within two years and adjusted at $45.65 \%$ annually. Using Indonesian non-financial firms as sample, Haron (2016) found that the adjustment speed towards target book total debt was $62.74 \%$ from year 2000 to 2009 . Their findings portrayed different SOA in different time frame and sample.

Given the past empirical evidence, it can be deduced that firms have their own target capital structure and attempt to adjust towards the target leverage when the actual leverage is deviated from the target leverage. This is in line to the dynamic capital structure theory stated in the study by Fischer et al., (1989) where the capital market imperfection prevents an instantaneous adjustment of the actual leverage to the optimal level. Hence, this study postulated that ASEAN firms would adjust towards target leverage within certain ranges. The hypothesis proposed was as follows:

\section{H1: There is a range of adjustment speed towards target debt for ASEAN firms.}

\section{METHODOLOGY}

\subsection{Data Source and Sample Frame}

This study employed the balanced panel data methodology to investigate the speed of adjustment towards target leverage. Generally, a balanced panel is used to reduce the possible bias from the estimation as a result of endogenous variables (Nguyen, 2015). The focus of this study was on four ASEAN countries namely Malaysia, Singapore, Indonesia and Thailand. These countries comprised 76\% of the Gross Domestic Product (GDP) of ASEAN based on 2016 statistics. The sample covered the period from 2007 to 2017. The total sample size contained 400 firms drawn from 100 firms of each country, which yielded 4400 observations for analysis. The selection of firms was based on the highest market capitalisation as at 31 December 2017.

Data for leverage and firm-specific variables were collected from Thomson One Banker, whereas ownership concentration data were collected from firms' annual report. In the attempt to generate balanced panel data, the requirements for firms to be included are: (i) the companies must be listed on the Bursa Malaysia (for the case of Malaysia), Singapore Exchange (for the case of Singapore), Indonesia Stock Exchange (for the case of Indonesia) and the Stock Exchange of Thailand (for the case of Thailand); (ii) the firms must be locally incorporated; (iii) the annual report for the period of 2007 to 2017 are available, and (iv) the financial data and ownership data for the period of 2007 to 2017 must be available, and when necessary, the missing values are supplemented through the firms' annual report and the companies' official websites.

In this study, the classification of industry was based on the Industry Classification Benchmark (ICB). Firms classified under finance industry were excluded from the sample as they have a distinctive regulatory requirement than non-financial firms. 


\subsection{Variables and Measurement}

In DCS studies, there is no clear specification regarding the use of market or book leverage. On one strand of literature, book leverage has been claimed as a better measure as it is not affected by outside factors that are not under firms' direct control (stock price fluctuations) (Fama \& French, 2002; Matemilola, Bany-Ariffin, Azman-Saini, \& Nassir, 2018). The book leverage is also viewed as more reliable proxy because the managers were said to prefer book value when making leverage decision (Graham \& Harvey, 2001); thus, it is better to reflect management target leverage ratios (Drobetz \& Wanzenried, 2006; Thies \& Klock, 1992).

Another strand of literature argued that market leverage is a more appropriate proxy than book leverage because its input is in weighted average cost of capital computations. In the meantime, it has been also claimed as a better measure to describe agency problems between creditors and equity holders (Chang, Chou, \& Huang, 2014; Devos et al., 2017; Zheka, 2010). Furthermore, the market leverage has been viewed as more superior because it is a forward-looking measure compared to book leverage that only measures what has taken place (Frank \& Goyal, 2009). However, the market leverage is biased of future expectation (Amjed, 2016). In addition, Oztekin and Flannery (2012) found that the result based on market leverage and book leverage did not differ much. Besides, Yin \& Ritter (2018) mentioned that the use of market leverage in dynamic capital structure can lead the estimated SOA to upward biased. Due to these reasons, this study used book leverage to measure the leverage.

The dependent variables used were book value total debt (BVTD), book value long-term debt (BVLTD) and book value short-term debt (BVSTD). In terms of the independent variable, the main interest of this study was the speed of adjustment (SOA) towards target leverage, which was calculated based on the 1 minus the coefficient of lagged leverage $\left(1-\gamma_{i t},\right)$. For the control variables, this study followed majority of previous studies that used set of firm characteristics such as firm size, tangibility, profitability, non-debt tax shield and firm growth as well as ownership concentration variables (Buvanendra et al., 2017; Ting, 2016). The measurement of these variables was listed as below:

Table 1. List of Variables Measurement

\begin{tabular}{|c|c|}
\hline Variables & Definition \\
\hline Book Value of Total Debt (BVTD) & The ratio of book value of total debt to book value total assets \\
\hline $\begin{array}{l}\text { Book Value of Long-term Debt } \\
\text { (BVLTD) }\end{array}$ & $\begin{array}{l}\text { The ratio of book value of long-term debt to } \\
\text { book value total assets }\end{array}$ \\
\hline $\begin{array}{l}\text { Book Value of Short-term Debt } \\
\text { (BVSTD) }\end{array}$ & $\begin{array}{l}\text { The ratio of book value of short-term debt to } \\
\text { book value total assets }\end{array}$ \\
\hline Firm Size (SIZE) & Natural logarithm of total sales \\
\hline Tangibility (TANG) & The ratio of tangible fixed assets to total assets \\
\hline Profitability (PROF) & The ratio of earnings before interest and taxes to total assets \\
\hline Non-debt tax shield (NDTS) & The ratio of depreciation to total assets \\
\hline Growth (MTB) & The ratio of market to book value \\
\hline Ownership Concentration (OC) & Percentage of shares held by top 1 shareholder. \\
\hline
\end{tabular}




\subsection{Specification Model}

To estimate the speed of adjustment towards leverage, this study adopted the partial adjustment model (PAM) (Ahmad \& Etudaiye-Muhtar, 2017; Chang et al., 2014; Flannery \& Rangan, 2006; Rashid, 2016). In general, the model was specified as below:

$$
L E V_{i t}-L E V_{i t-1}=\lambda\left(L E V_{i t}^{*}-L E V_{i t-1}\right)+\varepsilon_{i t}
$$

where $L E V_{i t}^{*}$ is the target leverage and estimate based on $\sum_{j=1}^{L} \beta_{j} X_{i t} . X_{i t}$ is a set of firm characteristics such as firm size (SIZE), tangibility (TANG), profitability (PROF), non-debt tax shield (NDTS) and firm growth (MTB) as well as ownership concentration (OC). $L E V_{i t-1}$ is the lagged leverage. $\varepsilon_{i t}$ is the error term. To control the time-specific factor, industry-specific factors and country-specific factors, time, industry and county dummies were added into the equation.

Substituting $X_{i t}$ into the Equation 1 and rearranging the equation, the following equation was obtained:

$$
\begin{aligned}
& L E V_{i t}^{*}=\lambda_{0} L E V_{i t-1}+\beta_{1} \operatorname{SIZE}_{i t}+\beta_{2} \text { TANG }_{i t}+\beta_{3} \text { PROF F }_{i t}+\beta_{4} N D T S_{i t}+\beta_{5} \text { MTB }_{i t}+ \\
& \beta_{6} \mathrm{OC}_{i t}+\text { yeardummies }_{i}+\text { industrydummies }_{i}+\text { countrydummies }_{i}+\varepsilon_{i t}
\end{aligned}
$$

$\lambda_{0}$ is $1-\gamma$. The $\gamma$ is equal to $1, \gamma=1$ when the adjustment is complete, meaning that the entire adjustment is made within one period and the firm at time $t$ is at its target leverage level. If it is less than $1, \gamma<1$, it means that the adjustment is below than the target level at time $\mathrm{t}$; however, if it is greater than $1, \gamma>1$, then the adjustment is over than the target level. From the $\gamma$ value, it can be interpreted that higher $\gamma$ explain a higher speed of adjustment and vice versa (Haron et al., 2013b).

\subsection{Estimation Method}

To achieve the study objective, the two-step SYS-GMM proposed by Blundell and Bond (1998) was utilised. In a dynamic model as Equation 2, the use of ordinary least squares and fixed effect model may not generate efficient and consistent estimators because OLS ignores time-invariant unobserved individual effect $\left(\eta_{i}\right)$ and endogeneity of $L E V_{i t-1}$. The FEM eliminates the $\eta_{i}$, but also resulted in inconsistent parameters if $\mathrm{T}$ is fixed regardless of the size of $\mathrm{N}$ as it also does not deal with the endogeneity of $L E V_{i t-1}$. (Nguyen, 2015). The results obtained for the estimation would be upward and downward biased on lagged dependent variable for OLS and FEM, respectively.

SYS-GMM is a system of two simultaneous equation including one in levels and the other in first differences. As such, the lagged levels of explanatory variables can be employed as instruments in the first-differenced equation, while the lagged first differences can be used as the instrumental variables for the level equation (Nguyen, 2015). Blundell and Bond (1998) proved the efficiency of SYS-GMM than its predecessor, the Diff-GMM.

The SYS-GMM can be estimated using two approaches, where one-step uses weighting matrices that are independent of the estimated parameters while two-step estimator uses optimal weighting matrices in which the moment conditions are weighted by a consistent estimate of the covariance 
matrix. In terms of efficiency, two-step estimator is asymptotically more efficient than one-step estimator. Thus, this study used two-step estimator as it is sufficient to generate consistent and efficient estimators. This technique has been also used by Ahmad and Etudaiye-Muhtar (2017), Buvanendra et al., (2017) and Drobetz and Wanzenried (2006).

For consistency, the SYS-GMM depends on several tests:

1) Wald test is a joint significant test for all the coefficients. The null hypothesis is that all coefficients on the determinants of the target ratio are jointly equal to zero. This means that if p-value is less than 0.05 , all the variables used were appropriate to explain the dependent variable.

2) Serial correlation is conducted to detect autocorrelation. First order serial correlation $\mathrm{AR}(1)$ may be rejected, but second order correlation $\mathrm{AR}(2)$ should not be rejected. If $\mathrm{AR}(2)$ is rejected, second or deeper lags instruments shall be used (Kasbi, 2009; Mileva, 2007; Yakovlev, 2014). The use of second or deeper lags instrument could improve the odds of capturing a real causal relationship in the dependent variables coefficients (Yakovlev, 2014). However, one should be cautious with the reduction of sample size with the use of second or deeper lag instruments. Nevertheless, if the number of observations is large enough, one may use all available lags to find valid instruments. The rule of thumb is to keep the number of instruments less than or equal to the number of groups (Mileva, 2007).

3) Sargan test is conducted for instrument validity. It is an over-identifying restriction test and is asymptotically contains $\chi^{2}$ distribution with $(s-q)$ degree of freedom where $s$ is the number if instruments and $q$ is the number of regressors in the original equation. The null hypothesis under this test is that the instruments are exogenous, meaning that all the instruments are valid.

\section{FINDINGS \& DISCUSSIONS}

Table 2: Descriptive Statistics

\begin{tabular}{llllll}
\hline \hline Variables & Min & Max & Mean & Median & S.D. \\
\hline BVTD & 0.0000 & 1.5235 & 0.2274 & 0.2071 & 0.1869 \\
BVLTD & 0.0000 & 1.4586 & 0.1246 & 0.0718 & 0.1431 \\
BVSTD & 0.0000 & 0.8974 & 0.0631 & 0.0152 & 0.1026 \\
SIZE & 5.9727 & 18.3299 & 12.6436 & 12.5842 & 1.6380 \\
TANG & 0.0001 & 0.9640 & 0.3400 & 0.3150 & 0.2182 \\
PROF & -0.8312 & 358.8370 & 0.1873 & 0.0892 & 5.4094 \\
NDTS & 0.0000 & 0.2883 & 0.0321 & 0.0269 & 0.0251 \\
MTB & -469.9700 & 246.4600 & 2.8271 & 1.5500 & 10.8915 \\
OC & 1.0700 & 98.1500 & 38.9299 & 36.7100 & 20.1303 \\
\hline \hline
\end{tabular}

Table 2 reports the descriptive statistics for key dependent and independent variables used in the dynamic capital structure regressions. As noticed from Table 2, all of the variables demonstrated a mean value greater than median. This suggests that all of the data were skewed to the right and were positively skewed. On average, BVTD has a mean value of 0.2274 and ranging from 0.0000 
to 1.5235 . BVLTD was ranged from minimum 0.0000 to maximum 1.4586 with mean of 0.1246 . Meanwhile, the mean of BVSTD was 0.0631 ranging from 0.0000 to 0.8974 . Through the minimum zero and maximum values of both, it can be deduced that some of ASEAN firms do not use debts and some of the firms use debts as the capital to support their operations. Furthermore, higher mean of long-term debt than short-term debt exhibits that ASEAN firms used more longterm debt to finance their operations compared to short-term debt.

From Table 2, it was noticed that the standard deviation (SD) of book debts were $0.2274,0.1246$ and 0.0631, respectively, to BVTD, BVLTD and BVSTD. This shows that total debt is the most volatile compared to long-term debt and short-term debt.

With respect to the firm characteristics, firm size (SIZE), tangibility (TANG), profitability, NDTS and MTB reported the mean of $12.6436,0.3400,0.1873,0.0321$ and 282.71 , respectively. In regards to OC, the mean value was 38.9299, which ranged from a minimum of 1.0700 and maximum of 98.1500 . Therefore, it can be concluded that ASEAN firms are generally closely held together. This finding has been affirmed with other studies such as that by (Claessens, Djankov, \& Lang, 2000; Deesomsak, Paudyal \& Pescetto, 2004; Driffield, Mahambare \& Pal, 2007).

Table 2: Pairwise correlation and variance-inflating factor results

\begin{tabular}{llllllll}
\hline \hline & OC & SIZE & TANG & PROF & NDTS & MTB & VIF \\
\hline OC & 1 & & & & & & 1.02 \\
SIZE & $0.0996^{* *}$ & 1 & & & & & 1.02 \\
TANG & 0.0190 & $0.0591^{* *}$ & 1 & & & 1.35 \\
PROF & $0.0286^{*}$ & $0.0142^{* *}$ & 0.0168 & 1 & & 1.00 \\
NDTS & $0.1129^{* *}$ & $0.0637^{* *}$ & $0.5032^{* *}$ & 0.0059 & 1 & & 1.39 \\
MTB & $-0.0320^{*}$ & $0.0844^{* *}$ & $0.0475^{* *}$ & 0.0030 & $0.5032^{* *}$ & 1 & 1.03 \\
& & & & & & Mean VIF & 1.13 \\
\hline \hline
\end{tabular}

Note: $* * p<.01, * p<.05, \dagger p<.10$.

Table 3 portrays the correlations between independent variables. All correlation coefficient values of independent variables were less than 0.6 in absolute terms; meanwhile, the variance inflating factor (VIF) result (1.13) was less than 10. Thus, it can be conjectured that the sample data did not suffer from multicollinearity problem.

Table 4: Generalised Method of Moments (Gmm) Results of Partial Adjustment Model (Pam) For Aggregate Asean Firms

\begin{tabular}{llll}
\hline \hline & Model 1 & Model 2 & Model 3 \\
\hline SOA & BVTD & BVLTD & BVSTD \\
BVTDit-1 & 0.3095 & 0.3749 & 0.4011 \\
BVLTDit-1 & $0.6905^{* *}$ & & \\
BVSTDit-1 & $(15.32)$ & & \\
Half-life & & $0.6251^{* *}$ & \\
& & $(24.24)$ & $0.5989^{* *}$ \\
& 1.87 & & $13.26)$ \\
\hline
\end{tabular}




\begin{tabular}{llll}
\hline OC & $-0.0019^{* *}$ & 0.0001 & $-0.0007^{*}$ \\
SIZE & $(-2.91)$ & $(0.30)$ & $(-2.02)$ \\
& $0.0282^{*}$ & $0.1634^{* *}$ & 0.0084 \\
TANG & $(2.31)$ & $(0.30)$ & $(1.44)$ \\
& 0.1533 & 0.0526 & 0.0142 \\
PROF & $(1.13)$ & $(0.95)$ & $(0.35)$ \\
& -0.0023 & 0.0025 & 0.0013 \\
NDTS & $(-1.01)$ & $(1.64)$ & $(0.92)$ \\
& 0.3212 & -0.7058 & 0.2172 \\
MTB & $(0.27)$ & $(-1.36)$ & $(0.60)$ \\
& -0.0006 & $-0.0013^{* *}$ & -0.0011 \\
Industry effect & $(-1.45)$ & $(-4.00)$ & $(-0.63)$ \\
Year fixed effect & Yes & yes & yes \\
Country effect & Yes & yes & yes \\
AR(2) (P-value) & Yes & yes & yes \\
Sargan test (P-value) & 0.0670 & 0.2275 & 0.2999 \\
Wald Test (P-value) & 0.3993 & 0.1561 & 0.1973 \\
Instruments & 0.0000 & 0.0000 & 0.0000 \\
\hline \hline
\end{tabular}

Note: ${ }^{* *} p<.01,{ }^{*} p<.05, \dagger p<.10$.

Table 4 provides the result of speed of adjustment towards target leverage and the determinant of target capital structure. Model 1, Model 2 and Model 3 were instrumented based on the dependent and independent variables owned lagged level ( $\mathrm{t}-2$ and deeper) and first differences ( $\mathrm{t}-1$ and deeper). This was done via the command of "xtdpd" in stata.

From the table, the wald-tests' result showed that the determinants used in this study can be considered as the explanatory of leverage ( $\mathrm{p}$-value $<0.05$ ). The sargan-tests' result suggests that the null hypothesis of over-identifying restriction was valid and cannot be rejected since all model $\mathrm{p}$-values were greater than 0.05 . This indicates that all models have valid instruments. In the meantime, the second order autocorrelation (AR(2)) tests' proved the absence of second order autocorrelation in the models. Therefore, the result suggests that all the dynamic estimators have been well specified.

Under Model 1, the coefficient of BVTDit-1 was 0.6905 , which was statistically significant at $1 \%$. This indicates that the adjustment cost towards target BVTD was 0.6905 while the adjustment speed for the selected ASEAN firms was 0.3095 (30.95\%). It would take 1.87 years for firms to reach half of the target BVTD from current BVTD. Based on the speed of adjustments, ASEAN firms are close by $69.05 \%$ of the gap between current and target MVTD within one year.

Under Model 2, the coefficient of BVLTDit-1 was 0.6251 (62.51\%), which was significant at $1 \%$. This result implies that the speed of adjustment towards target BVLTD for ASEAN firms was $31.70 \%$. The value tells that it would require 1.62 years for firms to reach half of the target BVLTD from the current BVLTD.

The coefficient of BVSTDit-1 in Model 3 was 0.5989 , which was statistically significant at $1 \%$. This denotes that the speed of adjustment was $40.11 \%$. Thus, it would take 1.35 years for ASEAN firms to reach half of the target BVSTD from current BVSTD. 
The result of SOA towards BVTD (30.95\%) was comparable and slightly slower than that of Getzmann et al., (2015) study demonstrating the SOA of 33\%. The result of this study was within their reported range per industry result in which they found that the SOA towards total debt were ranged from $25 \%$ to $45 \%$ for Asian countries. Compared to other western countries, the present result with book value leverage as dependent variable showed slower adjustment speed than Canada and the UK (35.4\% and 32\%, respectively) as reported in Drobetz et al., (2015). Likewise, it also reduced the adjustment speed compared to the UK (SOA- 45.2\%) in Rashid (2016) study. Nevertheless, it was quicker compared to the US (26.1\%) based on Drobetz et al., (2015) study. With the comparison from other Asian countries such as China and Sri Lanka, the results of this study presented slower adjustment speed. Yang et al., (2015) found an adjustment speed of 36.7\% for Chinese firms and Buvanendra et al., (2017) reported adjustment speed of $45.4 \%$ for Sri Lanka firms.

The SOA result in aggregation showed that ASEAN firms adjusted quicker towards short-term debt than long-term debt, regardless of whether or not the book or market leverage was used as firm leverage measurement. Differences in the SOA towards target capital structures reflected different costs of adjustment (Getzmann et al., 2015). This could be because of the long term debt covenants have higher adjustment costs and were sought for long term investment projects with investment that is comparatively hard to adjust in the short run (Amjed, 2016). Similar trends were reported a previous study; where, Rehman et al., (2016) reported quicker adjustment towards target short-term debt than long-term debt regardless of the firm life cycle stage ranging from $66 \%$ $90.5 \%$ and $43.5 \%$ to $75 \%$, respectively.

Since the result of all three models revealed a significant positive correlation of lagged debt ratios with dependent variables with a value of greater than zero but less than one, it implies an underadjusted of leverage for all selected ASEAN firms that adjust their leverage toward target level over time. Hence, this study deduced that there is a range of speed towards target debt for ASEAN firms; thus, H1 was accepted.

Table 5: Generalised Method of Moments (Gmm) Results for Individual Country

\begin{tabular}{|c|c|c|c|c|c|c|}
\hline & \multicolumn{3}{|c|}{ Malaysia } & \multicolumn{3}{|c|}{ "Singapore } \\
\hline & Model 1 & Model 2 & Model 3 & Model 1 & Model 2 & Model 3 \\
\hline & BVTD & BVLTD & BVSTD & BVTD & BVLTD & BVSTD \\
\hline SOA & 0.2911 & 0.4134 & 0.5491 & 0.4121 & 0.4184 & 0.6478 \\
\hline BVTD $_{t-1}$ & $\begin{array}{l}0.7089^{* * *} \\
(19.27)\end{array}$ & & & $\begin{array}{l}0.5879^{* * *} \\
(29.03)\end{array}$ & & \\
\hline BVLTD $_{\mathrm{t}-1}$ & & $\begin{array}{l}0.5866^{* *} \\
(23.08)\end{array}$ & & & $\begin{array}{l}0.5816^{* * *} \\
(21.92)\end{array}$ & \\
\hline BVSTD $_{t-1}$ & & & $\begin{array}{l}0.4509^{\text {** }} \\
(8.51)\end{array}$ & & & $\begin{array}{l}0.3522^{* *} \\
(16.25)\end{array}$ \\
\hline Half-life & 2.01 & 1.30 & 0.87 & 1.30 & 1.28 & 0.66 \\
\hline $\mathrm{OC}$ & $\begin{array}{l}0.0005 \\
(1.15)\end{array}$ & $\begin{array}{l}-0.00001 \\
(-0.03)\end{array}$ & $\begin{array}{l}0.0008 \\
(1.26)\end{array}$ & $\begin{array}{l}-0.0008^{* *} \\
(-3.91)\end{array}$ & $\begin{array}{l}-0.0003 \\
(-1.37)\end{array}$ & $\begin{array}{l}-0.0002 \\
(-1.26)\end{array}$ \\
\hline SIZE & $\begin{array}{l}0.0279^{\text {*** }} \\
(4.40)\end{array}$ & $\begin{array}{l}0.0209^{* * *} \\
(3.86)\end{array}$ & $\begin{array}{l}-0.0106 \\
(-1.16)\end{array}$ & $\begin{array}{l}-0.0079 \\
(-1.59)\end{array}$ & $\begin{array}{l}0.0022 \\
(0.68)\end{array}$ & $\begin{array}{l}0.0065 \dagger \\
(1.93)\end{array}$ \\
\hline TANG & $\begin{array}{l}0.0979^{\text {** }} \\
(2.59)\end{array}$ & $\begin{array}{l}0.0712 \\
(1.38)\end{array}$ & $\begin{array}{l}-0.1021 \\
(-1.64)\end{array}$ & $\begin{array}{l}0.7193^{* *} \\
(15.77)\end{array}$ & $\begin{array}{l}0.2241^{\text {*** }} \\
(5.43)\end{array}$ & $\begin{array}{l}0.0107 \\
(0.49)\end{array}$ \\
\hline
\end{tabular}




\begin{tabular}{|c|c|c|c|c|c|c|}
\hline PROF & $\begin{array}{l}-0.3532^{* *} \\
(-6.05)\end{array}$ & $\begin{array}{l}-0.2051^{* *} \\
(-3.65)\end{array}$ & $\begin{array}{l}-0.1954^{* *} \\
(-3.82)\end{array}$ & $\begin{array}{l}0.0048^{* *} \\
(3.34)\end{array}$ & $\begin{array}{l}0.0008 \\
(0.79)\end{array}$ & $\begin{array}{l}-0.0005 \\
(-0.78)\end{array}$ \\
\hline NDTS & $-1.2512^{* * *}$ & -0.3988 & $-1.2843^{* * *}$ & $-6.0144^{* *}$ & $-1.8683^{* *}$ & 0.1045 \\
\hline MTB & $\begin{array}{l}0.0030^{* * *} \\
(4.66)\end{array}$ & $\begin{array}{l}0.0020^{\text {*** }} \\
(2.71)\end{array}$ & $\begin{array}{l}-0.00006 \\
(-0.07)\end{array}$ & $\begin{array}{l}0.0023^{* * *} \\
(3.44)\end{array}$ & $\begin{array}{l}-0.00003 \\
(-0.10)\end{array}$ & $\begin{array}{l}-0.000006 \\
(-0.03)\end{array}$ \\
\hline Industry effect & yes & Yes & yes & yes & yes & yes \\
\hline Year fixed effect & yes & Yes & yes & yes & yes & yes \\
\hline Country effect & yes & Yes & yes & yes & yes & yes \\
\hline $\mathrm{AR}(2) \mathrm{p}$-value & 0.1690 & 0.2227 & 0.0525 & 0.1274 & 0.9944 & 0.1787 \\
\hline Sargan test $p$-value & 0.4745 & 0.2741 & 0.7366 & 0.1892 & 0.0654 & 0.1388 \\
\hline Wald Test $\mathrm{p}$-value & 0.0000 & 0.0000 & 0.0000 & 0.0000 & 0.0000 & 0.0000 \\
\hline \multirow[t]{2}{*}{ Instruments } & 71 & 56 & 50 & 75 & 64 & 56 \\
\hline & $\begin{array}{l}\text { Model } 1 \\
\text { BVTD }\end{array}$ & $\begin{array}{l}\text { Indonesia } \\
\text { Model } 2 \\
\text { BVLTD }\end{array}$ & $\begin{array}{l}\text { Model } 3 \\
\text { BVSTD }\end{array}$ & $\begin{array}{l}\text { Model } 1 \\
\text { BVTD }\end{array}$ & $\begin{array}{l}\text { Thailand } \\
\text { Model } 2 \\
\text { BVLTD }\end{array}$ & $\begin{array}{l}\text { Model } 3 \\
\text { BVSTD }\end{array}$ \\
\hline $\begin{array}{l}\text { SOA } \\
\text { BVTD }_{t-1}\end{array}$ & $\begin{array}{l}0.3881 \\
0.6119^{* *} \\
(33.06)\end{array}$ & 0.5510 & 0.5668 & $\begin{array}{l}0.3299 \\
0.6701^{* *} \\
(25.94)\end{array}$ & 0.4505 & 0.5700 \\
\hline BVLTD $_{t-1}$ & & $\begin{array}{l}0.4490^{* * *} \\
(24.63)\end{array}$ & & & $\begin{array}{l}0.5495^{* *} \\
(15.47)\end{array}$ & \\
\hline BVSTD $_{\mathrm{t}-1}$ & & & $\begin{array}{l}0.4332^{* * *} \\
(20.11)\end{array}$ & & & $\begin{array}{l}0.4300^{* * *} \\
(25.84)\end{array}$ \\
\hline Half-life & 1.41 & 0.87 & 0.83 & 1.73 & 1.16 & 0.82 \\
\hline $\mathrm{OC}$ & $\begin{array}{l}0.0010^{\text {*** }} \\
(4.64)\end{array}$ & $\begin{array}{l}0.0012^{\text {** }} \\
(3.47)\end{array}$ & $\begin{array}{l}-0.0006^{*} \\
(-2.42)\end{array}$ & $\begin{array}{l}-0.0011^{\text {** }} \\
(-2.57)\end{array}$ & $\begin{array}{l}-0.0005 \\
(-1.12)\end{array}$ & $\begin{array}{l}0.0010^{* * *} \\
(4.73)\end{array}$ \\
\hline & $0.0137^{* *}$ & $-0.0399^{* *}$ & $0.0195^{* *}$ & $0.0134^{* *}$ & $0.0377^{* *}$ & $0.0213^{* *}$ \\
\hline SIZE & $\begin{array}{l}(2.83) \\
-0.0905^{* *}\end{array}$ & $\begin{array}{l}(-4.04) \\
0.0430\end{array}$ & $\begin{array}{l}(7.73) \\
-0.0653^{* *}\end{array}$ & $\begin{array}{l}(2.15) \\
0.0494^{* *}\end{array}$ & $\begin{array}{l}(4.61) \\
0.2328^{* *}\end{array}$ & $\begin{array}{l}(4.86) \\
-0.0141\end{array}$ \\
\hline TANG & $\begin{array}{l}(-2.28) \\
-0.6149^{* *}\end{array}$ & $\begin{array}{l}(1.29) \\
-0.1940^{* *}\end{array}$ & $\begin{array}{l}(-2.84) \\
-0.1909^{* *}\end{array}$ & $\begin{array}{l}(1.66) \\
-0.4490^{* *}\end{array}$ & $\begin{array}{l}(5.94) \\
-0.1306^{* *}\end{array}$ & $\begin{array}{l}(-0.46) \\
0.3721^{* *}\end{array}$ \\
\hline PROF & $\begin{array}{l}(-17.13) \\
0.4843^{*}\end{array}$ & $\begin{array}{l}(-4.64) \\
1.0601^{* *}\end{array}$ & $\begin{array}{l}(-9.62) \\
-0.1653\end{array}$ & $\begin{array}{l}(-27.45) \\
-1.3627^{* *}\end{array}$ & $\begin{array}{l}(-4.47) \\
-2.8758\end{array}$ & $\begin{array}{l}(-18.30) \\
-1.2027^{* *}\end{array}$ \\
\hline NDTS & $\begin{array}{l}(2.10) \\
0.00004\end{array}$ & $\begin{array}{l}(2.80) \\
-0.0010^{* *}\end{array}$ & $\begin{array}{l}(-1.42) \\
0.0004\end{array}$ & $\begin{array}{l}(-3.32) \\
0.0038^{*}\end{array}$ & $\begin{array}{l}(-7.82) \\
-0.0029\end{array}$ & $\begin{array}{l}(-6.15) \\
-0.0083^{\text {** }}\end{array}$ \\
\hline МТВ & $(0.57)$ & $(-15.85)$ & $(1.19)$ & $(2.20)$ & $(-1.40)$ & $(-7.80)$ \\
\hline Industry effect & yes & Yes & yes & yes & yes & yes \\
\hline Year fixed effect & yes & Yes & yes & yes & yes & yes \\
\hline Country effect & yes & Yes & yes & yes & yes & yes \\
\hline $\mathrm{AR}(2) \mathrm{p}$-value & 0.4588 & 0.3458 & 0.5323 & 0.0702 & 0.1466 & 0.6351 \\
\hline Sargan test p-value & 0.7421 & 0.5150 & 0.3369 & 0.2661 & 0.2329 & 0.4109 \\
\hline Wald Test p-value & 0.0000 & 0.0000 & 0.0000 & 0.0000 & 0.0000 & 0.0000 \\
\hline Instruments & 75 & 67 & 72 & 70 & 70 & 79 \\
\hline
\end{tabular}

Note: $* * p<.01, * p<.05, \dagger p<.10$.

From Table 5, all of the models showed that the instruments used in the estimation model were valid. As observed, Singapore displayed the quickest adjustment speed towards BVTD (41.21\%), whereas Malaysia has the slowest adjustment speed towards BVTD (29.11\%) when the results between countries were compared. In regard to the speed of adjustment towards BVLTD, Indonesia exhibited the quickest adjustment speed (55.10\%) while Malaysia has the slowest adjustment speed 
(41.34\%). The result on the adjustment speed towards BVSTD indicates that Singapore has the quickest adjustment (64.78\%) while Malaysia has the slowest speed (54.91\%) towards BVSTD.

In comparison with previous studies, the present results shows that Malaysia, Singapore and Thailand have slower adjustment speed towards BVTD than that of Nor et al., (2011) study, where the SOA found were 57\%, 43.68\% and $65.46 \%$ for Malaysia, Singapore and Thailand, respectively. However, Malaysia adjustment speed was faster than that of Ting (2016) result (21\%). Based on Nor et al., (2011) result, the result of SOA towards BVLTD obtained in this study were faster for Malaysia but slower for Singapore and Thailand where the authors found the adjustment speed of 34.66, 42.54 and 47.30\%, respectively. For the SOA towards BVSTD, the result exhibited faster adjustment speed for Malaysia and Thailand, but slower adjustment speed for Singapore. Nor et al., (2011) recorded the speed of 51.61, 97.34 and 30.82\%. In the meantime, this study result $(29.03 \%)$ presented slower adjustment speed for Indonesian firms compared to that of Haron (2016) (62.74\%).

The varied ranges of SOA towards leverage showed consistency with Oztekin and Flannery (2012) study in which they conjectured that institutional differences are the factors behind the variations. The results are in line with the dynamic trade-off theory where imperfect capital market and transaction costs may prevent firms from fully adjusting towards the target leverage (Fischer et al., 1989).

\section{CONCLUSION AND RECOMMENDATIONS}

This study has been conducted to investigate the speed of adjustment towards target leverage for ASEAN countries. Based on the findings, this study confirmed and concluded that all firms have their own speed of adjustment, in which they would adjust towards the target leverage depending on the extent of the adjustment cost. The lower is the adjustment cost, the quicker is the SOA; and vice versa. The present findings were consistent with the assumptions of the DCS Theory. In addition, this study also stressed out the importance of institutional differences in examining the SOA where, within a similar region (ASEAN), the SOA obtained were different among the four individual countries examined.

Although insightful findings to the DCS literature have been presented in this study, the academicians shall contentiously generalise the findings. First, only four out of ten ASEAN countries were selected in this study due to the reason that this study was unable to collect a full 100 firms' ownership concentration data from the others to generate a balanced panel. As the ownership concentration data were collected from each of the firms' annual report, the language barriers and missing data from the reported annual report caused a hardship to have a full data over time. Second, this study has used industry dummies to capture the unobservable industry differences; thus, academicians and policy makers shall concern the capital structure decision formed by different category of industries because different industry normally form different decisions especially the highly regulated industries. Lastly, a study that concerns on how the firm adjust towards the target leverage like ours may not sufficiently explain how to quickly a firm can close the deviation so that actual leverage can move as closer as the target leverage. As target leverage is an optimal level that maximise firms' value, factors that influence the SOA should be 
seriously considered. These limitations present the need for further development in the area of capital structure studies.

\section{REFERENCES}

Ahmad, R., \& Etudaiye-Muhtar, O. F. (2017). Dynamic Model of Optimal Capital Structure: Evidence from Nigerian Listed Firms. Global Business Review, 18(3), 1-15. doi: $10.1177 / 0972150917692068$

Amjed, S. (2016). Dynamics of Financial Structure Adjustments and Firms 'Financial Performance (PhD Thesis) (University of Science \& Technology, Islamabad). Retrieved from https://cust.edu.pk/static/uploads/2018/10/Sohail-Amjed.pdf

Antonczyk, R. C., \& Salzmann, A. J. (2014). Overconfidence and Optimism: The Effect of National Culture on Capital Structure. Research in International Business and Finance, 31, 132-151. doi: 10.1016/j.ribaf.2013.06.005

Banerjee, S., Heshmati, A., \& Wihlborg, C. (1999). The Dynamics of Capital Structure. In New York University-Salomon Center-Leonard N. Stern School of Business. Retrieved from https://pdfs.semanticscholar.org/d963/73c220255e4d055d172f0ad7df58834982dc.pdf

Berglöf, E. (1990). Capital Structure as a Mechanism of Control: A Comparison of Financial Systems. London: Sage Publications.

Blundell, R., \& Bond, S. (1998). Initial Conditions and Moment Restrictions in Dynamic Panel Data Models. Journal of Econometrics, 87(1), 115-143. doi: 10.1016/S03044076(98)00009-8

Buvanendra, S., Sridharan, P., \& Thiyagarajan, S. (2017). Firm Characteristics, Corporate Governance and Capital Structure Adjustments: A Comparative Study of Listed Firms in Sri Lanka and India. IIMB Management Review, 29(4), 245-258. doi: 10.1016/j.iimb.2017.10.002

Chang, Y.-K., Chou, R. K., \& Huang, T.-H. (2014). Corporate Governance and The Dynamics of Capital Structure: New Evidence. Journal of Banking \& Finance, 48, 374-385. doi: 10.1016/j.jbankfin.2014.04.026

Cheng, Y., \& Green, C. J. (2008). Taxes and Capital Structure: A Study of European Companies. Ssrn. doi: 10.1111/j.1467-9957.2008.01082.x

Claessens, S., Djankov, S., \& Lang, L. H. . (2000). The Separation of Ownership and Control in East Asian Corporations. Journal of Financial Economics, 58(1-2), 81-112. doi: 10.1016/S0304-405X(00)00067-2

Cook, D. O., \& Tang, T. (2010). Macroeconomic Conditions and Capital Structure Adjustment Speed. Journal of Corporate Finance, 16(1), 73-87. doi: 10.1016/j.jcorpfin.2009.02.003

Dang, V. A., Kim, M., \& Shin, Y. (2014). Asymmetric Adjustment toward Optimal Capital Structure: Evidence from A Crisis. International Review of Financial Analysis, 33, 226-242. doi: 10.1016/j.irfa.2014.02.013

Deesomsak, R., Paudyal, K., \& Pescetto, G. (2004). The Determinants of Capital Structure: Evidence from The Asia Pacific Region. Journal of Multinational Financial Management, 14, 387-405. doi: 10.1016/j.mulfin.2004.03.001

Devos, E., Rahman, S., \& Tsang, D. (2017). Debt Covenants and The Speed of Capital Structure Adjustment. Journal of Corporate Finance, 45, 1-18. doi: 10.1016/j.jcorpfin.2017.04.008 
Driffield, N., Mahambare, V., \& Pal, S. (2007). How does Ownership Structure affect Capital Structure and Firm Value? Economics of Transition, 15(3), 535-573. doi: 10.1111/j.14680351.2007.00291.x

Drobetz, W., Schilling, D. C., \& Schroder, H. (2015). Heterogeneity in the Speed of Capital Structure Adjustment across Countries and over the Business Cycle. European Financial Management, 21(5), 936-973. doi: 10.1111/eufm.12048

Drobetz, W., \& Wanzenried, G. (2006). What Determines the Speed of Adjustment to the Target Capital Structure? Applied Financial Economics, 16(13), 941-958. doi: 10.1080/09603100500426358

Fama, E. F., \& French, K. R. (2002). Testing Trade-Off and Pecking Order Predictions About Dividends and Debt. The Review of Financial Studies, 15(1), 1-33. doi: 10.1093/rfs/15.1.1

Faulkender, M., Flannery, M. J., Watson, K., \& Smith, J. M. (2012). Cash Flows and Leverage Adjustments. Journal of Financial Economics, 103, 632-646. doi: 10.1016/j.jfineco.2011.10.013

Fischer, E. O., Heinkel, R., \& Zechner, J. (1989). Dynamic Capital Structure Choice : Theory and Tests. Journal of Finance, 44(1), 19-40. doi: 10.2307/2328273

Flannery, M. J., \& Rangan, K. P. (2006). Partial Adjustment toward Target Capital Structures. Journal of Financial Economics, 79(3), 469-506. doi: 10.1016/j.jfineco.2005.03.004

Fosberg, R. H. (2012). Determinants of Short-Term Debt Financing. Research in Business and Economics Journal, 6(July), 1-12. $\quad$ Retrieved from https://pdfs.semanticscholar.org/8e68/03f575f33e9fb3cd4cebd181fad2abe161cd.pdf

Frank, M. Z., \& Goyal, V. K. (2009). Capital Structure Decisions: Which Factors Are Reliably Important? Financial Management, 38(1), 1-37. doi: 10.1111/j.1755-053X.2009.01026.x

Getzmann, A., Lang, S., \& Spremann, K. (2014). Target Capital Structure and Adjustment Speed in Asia. Asia-Pacific Journal of Financial Studies, 43(1), 1-30. doi: 10.1111/ajfs. 12038

Getzmann, A., Lang, S., \& Spremann, K. (2015). Target Capital Structure Determinants and Speed of Adjustment Analysis to Address the Keynes-Hayek Debate. Journal of Reviews on Global Economics, 4, 225-241. doi: 10.6000/1929-7092.2015.04.23

Graham, J. R., \& Harvey, C. R. (2001). The Theory and Practice of Corporate Finance: Evidence from the Field. Journal of Financial Economics, 60(2-3), 187-243. doi: 10.1016/S0304405X(01)00044-7

Haron, R. (2014). Firms' Speed of Adjustment and Rational Financing Behaviour: Malaysian Evidence. Journal for Global Business Advancement, 7(2), 151. doi: 10.1504/JGBA.2014.063869

Haron, R. (2016). Do Indonesian Firms Practice Target Capital Structure? A Dynamic Approach. Journal of Asia Business Studies, 10(3), 318-334. doi: 10.1108/JABS-07-2015-0100

Haron, R., Ibrahim, K., Nor, F. M., \& Ibrahim, I. (2013a). Dynamic Adjustment towards Target Capital Structure: Thailand Evidence. Jurnal Pengurusan, 39, 73-82. Retrieved from https://pdfs.semanticscholar.org/784b/9d309fcf05c4235c717c7e01a8ed83f226c6.pdf

Haron, R., Ibrahim, K., Nor, F. M., \& Ibrahim, I. (2013b). Factors Affecting Speed of Adjustment to Target Leverage: Malaysia Evidence. Global Business Review, 14(2), 243-262. doi: 10.1177/0972150913477469

Jensen, M. C. (1986). Agency Costs of Free Cash Flow, Corporate Finance, and Takeovers. The American Economic Review, 76(2), 323-329. doi: 10.2307/1818789

Kane, A., Marcus, A. J., \& McDonald, R. L. (1984). How Big is the Tax Advantage to Debt? The Journal of Finance, 39(3), 841-853. doi: 10.1111/j.1540-6261.1984.tb03678.x 
Kasbi, S. (2009). Ownership Concentration and Capital Structure Adjustments. In Working Paper. Retrieved from http://citeseerx.ist.psu.edu/viewdoc/download?doi=10.1.1.534.7538\&rep= rep1\&type $=$ pdf

Lööf, H. (2004). Dynamic Optimal Capital Structure and Technical Change. Structural Change and Economic Dynamics, 15(4), 449-468. doi: 10.1016/j.strueco.2003.05.001

M'ng, J. C. P., Rahman, M., \& Sannacy, S. (2017). The Determinants of Capital Structure: Evidence from Public Listed Companies in Malaysia, Singapore and Thailand. Cogent Economics \& Finance, 5(1), 1-34. doi: 10.1080/23322039.2017.1418609

Matemilola, B. T., Bany-Ariffin, A. N., Azman-Saini, W. N. W., \& Nassir, A. M. (2018). Does Top Managers' Experience affect Firms' Capital Structure? Research in International Business and Finance, 45, 488-498. doi: 10.1016/j.ribaf.2017.07.184

Mileva, E. (2007). Using Arellano-Bond Dynamic Panel GMM Estimators in Stata. Retrieved from https://www.researchgate.net/file.PostFileLoader.html?id=575fcb0a217e200cb31d2f1f\&as setKey=AS\%3A372807700631552\%401465895690276

Myers, S. C. (1977). Determinants of Corporate Borrowing. Journal of Financial Economics, 5(2), 147-175. doi: 10.1016/0304-405X(77)90015-0

Myers, S. C., \& Majluf, N. S. (1984). Corporate Financing and Investment Decisions when Firms have Information that Investors do not have. Journal of Financial Economics, 13(2), 187221. doi: 10.1016/0304-405X(84)90023-0

Nejad, N. R., \& Wasiuzzaman, S. (2015). Multilevel Determinants of Capital Structure: Evidence from Malaysia. Global Business Review, 16(2), 199-212. doi: 10.1177/0972150914564274

Nguyen, T. Van. (2015). Corporate Governance Structures and Financial Performance: A Comparative of Study of Publicly Listed Companies in Singapore and Vietnam (University of Waikato). Retrieved from https://researchcommons.waikato.ac.nz/bitstream/handle/ 10289/9437/thesis.pdf? sequence=3\&isAllowed $=y$

Nor, F. M., Haron, R., Ibrahim, K., Ibrahim, I., \& Alias, N. (2011). Determinants of Target Capital Structure: Evidence on South East Asia Countries. Journal of Business and Policy Research, 6(3), 39-61. Retrieved from http://irep.iium.edu.my/id/eprint/10181

Oztekin, O., \& Flannery, M. J. (2012). Institutional Determinants of Capital Structure Adjustment Speeds. Journal of Financial Economics, 103(1), 88-112. doi:10.1016/j.jfineco.2011.08.014

Rashid, A. (2016). Does Risk affect Capital Structure Adjustments? The Journal of Risk Finance, 17(1), 80-92. doi:10.1108/JRF-06-2015-0060

Rehman, A. ur, Wang, M., \& Yu, H. (2016). Dynamics of Financial Leverage across Firm Life Cycle in Chinese Firms: An Empirical Investigation using Dynamic Panel Data Model. China Finance and Economic Review, 4(1), 19. doi:10.1186/s40589-016-0041-z

Schröder, R. M., \& Sosman, E. E. (2016). An Empirical Investigation of Dynamic Capital Structure Theories - Evidence from Europe (Master Thesis) (Copenhagen Business School). Retrieved from https://studenttheses.cbs.dk/bitstream/handle/10417/6188/Robin_Maximilian_ Schröder_Edward_Sosman.pdf?sequence $=1$

Soekarno, S., Kitri, M. L., \& Utomo, S. (2015). The Speed of Adjustment to Capital Structure target before and after Financial Crisis: Evidence from Indonesian State Owned Enterprises. International Journal of Applied Business and Economic Research, 13(7), 5375-5387. Retrieved from https://www.researchgate.net/profile/Subiakto_Soekarno/publication /302209257_The_speed_of_adjustment_to_capital_structure_target_before_and_after_fina ncial_crisis_Evidence_from_Indonesian_state_owned_enterprises/links/57a7390b08aefe61 $67 \mathrm{bb} 4 \mathrm{c} 16 /$ The-speed-of 
Soekarno, S., Kitri, M. L., \& Utomo, S. (2016). Capital Structure Determinants and the Speed of Adjustment Towards Capital Structure Target: Evidence from Indonesian State-Owned Enterprises. International Journal of Monetary Economics and Finance, 9(4), 388-400. doi: 10.1504/IJMEF.2016.080081

Thies, C., \& Klock, M. (1992). Determinants of Capital Structure. Review of Financial Economics, 1(2), 40-52. Retrieved from doi: 10.1002/j.1873-5924.1992.tb00548.x

Ting, I. W. K. (2016). Estimating Dynamic Panel Model of Leverage Decision: Evidence from Malaysia. Procedia Economics and Finance, 35, 267-273. doi: 10.1016/S22125671(16)00033-2

Yakovlev, P. A. (2014). State Economic Prosperity and Taxation (No. 14-19). Retrieved from https://www.mercatus.org/system/files/Yakovlev-State-Economic-Prosperity.pdf

Yang, Y., Albaity, M., \& Hassan, C. H. Bin. (2015). Dynamic Capital Structure in China: Determinants and Adjustment Speed. Investment Management and Financial Innovations, 12(2), 195-204. Retrieved from https://businessperspectives.org/images/pdf/applications/ publishing/templates/article/assets/6783/imfi_en_2015_02cont_Yang.pdf

Yin, Q. E., \& Ritter, J. R. (2019). The Speed of Adjustment to the Target Market Value Leverage is Slower Than You Think. Journal of Financial and Quantitative Analysis, 1-66. doi: 10.1017/S0022109019000516

Zheka, V. (2010). The Impact of Corporate Governance Practices on Dynamic Adjustment of Capital Structure of Companies in Ukraine. In EERC Working Paper Series (No. 10/07E). Retrieved from http://eercnetwork.com/default/download/creater/working_papers/file/ 932e091c4ba9e72c5137a5a68fd6a9972ce557f3.pdf

Zhu, T. T. (2014). Capital Structure in Europe: Determinants, Market Timing and Speed of Adjustment (PhD Thesis) (University of Leicester). Retrieved from https://lra.le.ac.uk/bitstream/2381/33020/1/\%21Tingting Zhu_Capital Structure in Europe.pdf 